\title{
A FILOSOFIA DE LUDWIG WITTGENSTEIN À LUZ DO DIAGNÓSTICO DE AUTISMO
}

\begin{abstract}
“O trabalho em filosofia [...] é, na realidade, mais um trabalho sobre si próprio. Sobre a nossa própria interpretação. Sobre a nossa maneira de ver as coisas (e sobre o que delas se espera)" (WITTGENSTEIN, 1992a [1958], p. 33).
\end{abstract}

\section{Gustavo Augusto Fonseca Silva ${ }^{1}$}

Universidade Federal de Minas Gerais (UFMG)

http://orcid.org/0000-0001-7427-4504

E-mail: fonsecaugusto@hotmail.com

\section{RESUMO:}

Em Meu pensamento filosófico, Bertrand Russell afirma que a segunda filosofia de Ludwig Wittgenstein lhe parecia inteiramente ininteligível e constituída de doutrinas positivas triviais e de doutrinas negativas infundadas. Essas críticas ainda hoje são largamente consideradas como decorrentes do fato de Russell não ter compreendido as ideias tardias de Wittgenstein. Em oposição a esse julgamento, neste artigo argumenta-se que o diagnóstico póstumo de que Wittgenstein era autista suscita uma nova interpretação tanto de suas doutrinas positivas quanto de suas doutrinas negativas, levando a uma revalorização do parecer de Russell sobre elas.

PALAVRAS-CHAVE: Ludwig Wittgenstein; Segunda filosofia; Autismo.

\section{LUDWIG WITTGENSTEIN'S PHILOSOPHY IN THE LIGHT OF A DIAGNOSIS OF AUTISM}

\begin{abstract}
:
In My Philosophical Development, Bertrand Russell states that Ludwig Wittgenstein's second philosophy seemed completely unintelligible, composed by trivial positive doctrines and unfounded negative doctrines. Such critique is still currently considered a development of Russell's misunderstanding of Wittgenstein's later ideas. In opposition to that judgement, this article argues that Wittgenstein's posthumous diagnosis of autism provides a new interpretation of his positive doctrines and of his negative doctrines alike, proposing a revaluation of Russell's reaction to them.
\end{abstract}

KEYWORDS: Ludwig Wittgenstein; Second philosophy; Autism.

\footnotetext{
1 Doutorando em Linguística Teórica e Descritiva na Universidade Federal de Minas Gerais (UFMG), Belo Horizonte - MG, Brasil.
}

SILVA, Gustavo Augusto Fonseca. A filosofia de Ludwig Wittgenstein à luz do diagnóstico de autismo. Griot : Revista de Filosofia, Amargosa - BA, v.19, n.1, p.226-253, fevereiro, 2019. 


\section{Introdução}

No ensaio "Private experience and sense data", publicado no Oxford Handbook of Wittgenstein, Paul Snowdon afirma com razão que Wittgenstein é fundamentalmente um pensador negativo. Como bem observa Snowdon, o objetivo de Wittgenstein é primariamente estabelecer alegações da forma Não [P], ou ainda: "Nós não deveríamos pensar que $\mathrm{P} "$. Esse objetivo, prossegue Snowdon, não apenas é evidente na filosofia tardia de Wittgenstein como está em sintonia com sua concepção oficial e dominante da tarefa apropriada da filosofia: "Mostrar à mosca a saída do vidro" (WITTGENSTEIN, 1999 [1953], § 309). Assim, argumenta Snowdon, o significado da declaração de Wittgenstein de que "o filósofo trata uma questão como uma doença" (ibid., § 255) é que a tarefa da filosofia, concebida apropriadamente, é esclarecer e curar erros filosóficos. "A boa filosofia tira os pensadores de estados cognitivos desordenados (ou patológicos)", resume Snowdon (p. 404). Essa concepção filosófica, no entanto, depara-se com o sério problema de que "as Investigações raramente identificam os alvos de seus ataques" (GLOCK, 1998 [1996], p. 223), o que levou alguns leitores a criticar Wittgenstein "afirmando que ele parece estar exorcizando concepções que ninguém jamais sustentou" (ibid.). De fato, como ponderou Robert Fogelin (1995 [1976], p. 109), nas Investigações filosóficas "Wittgenstein gasta uma energia enorme exorcizando comprometimentos filosóficos - ao que parece - que ninguém sustentou". No $\S 27$, por exemplo, Wittgenstein afirma:

[...] fazemos as coisas mais diferentes com nossas frases. Pensemos apenas nas exclamações. Com todas as suas funções distintas:

Água!

Fora!

Ai!

Socorro!

Bonito!

Não!

Você ainda está inclinado a chamar essas palavras de "denominações de objetos"? objetos"?

Mas quem já esteve inclinado a chamar essas palavras de "denominações de

No $§ 11$, por sua vez, Wittgenstein afirma:

Com efeito, o que nos confunde é a uniformidade da aparência das palavras, quando estas nos são ditas, ou quando com elas nos defrontamos na escrita e na imprensa. Pois seu emprego não nos é tão claro. E especialmente não o é quando filosofamos!

"Eu confesso que não acho essa linha de raciocínio particularmente persuasiva", comentou o próprio Fogelin (1995 [1976], p. 113). "É difícil acreditar que os filósofos tenham sido enganados - e profundamente enganados - pela mera aparência (ou som) da linguagem."

${ }^{2}$ As traduções das citações de obras não publicadas em português foram feitas pelo autor.

SILVA, Gustavo Augusto Fonseca. A filosofia de Ludwig Wittgenstein à luz do diagnóstico de autismo. Griot : Revista de Filosofia, Amargosa - BA, v.19, n.1, p.226-253, fevereiro, 2019. 
Em outros textos de sua filosofia intermediária e tardia, Wittgenstein também gasta uma energia enorme exorcizando comprometimentos filosóficos que aparentemente ninguém sustentou. No Livro azul (p. 21-22), por exemplo, Wittgenstein afirma:

\begin{abstract}
As questões "O que é o comprimento?", “O que é o sentido?", "O que é o número um?", etc. causam-nos um constrangimento mental. Sentimos que para lhes dar respostas deveríamos apontar para algo e contudo sentimos que não podemos apontar para nada. (Enfrentamos uma das grandes fontes da desorientação filosófica: um substantivo faz-nos procurar uma coisa que lhe corresponda.)

[...] Numa palavra: "perguntemos o que é a explicação do sentido, visto que seja o que for que ela explique, isso será o sentido". O estudo da gramática da expressão "explicação do sentido" revelar-nos-á algo sobre a gramática da palavra "sentido" e curar-nos-á da tentação de procurar à nossa volta um objeto a que se pudesse chamar "o sentido".
\end{abstract}

Mas a quem as questões "O que é o comprimento?", "O que é o sentido?", “O que é o número um?", etc. causam um constrangimento mental? Quem sente que para lhes dar respostas deveria apontar para algo e contudo sente que não pode apontar para nada? Quem enfrenta esta que seria uma das grandes fontes da desorientação filosófica: um substantivo o faz procurar uma coisa que lhe corresponda? E quem precisaria ser curado da tentação de procurar à sua volta um objeto a que se pudesse chamar "o sentido"? Ora, Wittgenstein parece estar curando "constrangimentos mentais" que ninguém jamais sofreu. Não admira, portanto, que Piero Sraffa, a cujo "estímulo" Wittgenstein atribui no prefácio das Investigações filosóficas "as ideias mais fecundas" da obra, tenha lhe perguntado certa vez, evidentemente tentando "estimulá-lo": "Mas alguém realmente já fez esta ou aquela confusão que você ridiculariza?" (MCGUINNESS, 2002, p. 165). Tampouco admira que Frank Ramsey muitas vezes considerasse o resultado das reflexões filosóficas de Wittgenstein trivial (WITTGENSTEIN, 1992a [1958], p. 34) e desse de ombros dizendo que era evidente sua elucidação de algo (WITTGENSTEIN, 2010a [1997], p. 28-29). Muito menos admira que Bertrand Russell tenha rejeitado veementemente a filosofia tardia de Wittgenstein, julgando suas doutrinas positivas triviais e suas doutrinas negativas infundadas (RUSSELL, 1960 [1959], p. 193).

As críticas de Russell à segunda filosofia de Wittgenstein, porém, na opinião de boa parte dos wittgensteinianos, deveram-se à sua incompreensão das ideias de seu ex-aluno (e.g. DILMAN, 2002) ou mesmo a um certo "ressentimento (...) por sentir-se filosoficamente isolado" (MONK, 1995 [1990], p. 419) depois da ascensão de Wittgenstein. Em detrimento dessas explicações, neste artigo será defendida a tese de que as doutrinas positivas do "segundo" Wittgenstein são realmente triviais e que suas doutrinas negativas são de fato infundadas. Mas não apenas isso. Levando em consideração que psiquiatras contemporâneos como Michael Fitzgerald (2000), Christopher Gillberg (2002) e Yoshiki Ishisaka (2003a e 2003b) diagnosticaram Wittgenstein postumamente como autista, será mostrado como muda de aspecto "o que sua obra tem a ver com ele" (MONK, 1995 [1990], p. 16) à luz desse diagnóstico - tal qual o pato-coelho de Joseph Jastrow. O objetivo ao fazê-lo é explicitar como Wittgenstein filosofava sobre suas dificuldades comportamentais e cognitivas,

SILVA, Gustavo Augusto Fonseca. A filosofia de Ludwig Wittgenstein à luz do diagnóstico de autismo. Griot : Revista de Filosofia, Amargosa - BA, v.19, n.1, p.226-253, fevereiro, 2019. 
refletindo-se em seus textos tanto as suas "idiossincrasias pessoais e singularidades de temperamento" (JANIK; TOULMIN, 1991 [1973], p. 4) quanto os seus "constrangimentos mentais", os quais ele compreensivelmente estendeu às demais pessoas (em especial, aos demais filósofos).

Dada a natureza deste trabalho, é necessário deixar claro que, ao se propor reinterpretar a filosofia de Wittgenstein à luz do diagnóstico póstumo de autismo sobretudo suas doutrinas negativas -, não se está fazendo uma crítica ad hominem. Pelo contrário: à luz desse diagnóstico, parece impossível não concordar com a afirmação de Russell de que Wittgenstein era "um ser humano admirável" (RUSSELL, 1967 [1950], II, p. 135). Na verdade, muito mais admirável do que Russell jamais poderia imaginar. No entanto, é inegável que tal reinterpretação põe em xeque toda a escola, tão criticada pelo próprio Russell (1960 [1959], p. 193), que encontrou "importante sabedoria" nas páginas das Investigações filosóficas.

\section{A singularidade de Wittgenstein}

Em 27 de janeiro de 1937, Wittgenstein anotou em seu caderno, enquanto viajava para Skjolden, um vilarejo norueguês à beira do fiorde Sogne, onde havia construído em 1913 uma cabana para viver isolado: "Certamente sou singular em muitas coisas \& por isso, muitas pessoas se comportam de maneira comum quando comparadas comigo; mas em que consiste minha singularidade?" (WITTGENSTEIN, 2010a [1997], p. 109). Como dito na Introdução, de acordo com psiquiatras contemporâneos, a singularidade de Wittgenstein decorria de ele ser autista. Conforme esses especialistas, são evidências desse quadro, entre outras:

(1) o fato de ele só ter começado a falar e a andar aos 4 anos de idade (MONK, 1995 [1990], p. 27 e p. 401);

(2) suas limitadas expressões faciais e seu olhar fixo, perceptíveis em suas fotografias;

(3) sua voz peculiar - "Um tom mais alto que a voz normal de um homem", segundo Norman Malcolm (1990 [1958], p. 36);

(4) seu comportamento incomum - Como tantas outras pessoas que conviveram com Wittgenstein, Malcolm lembrava-se do amigo como "um personagem misterioso e excêntrico" (ibid., p. 68). "Ele era uma figura curiosa, facilmente irritável e excêntrica, com hábitos nada ingleses de vestir e de opinar socialmente" (JANIK; TOULMIN, 1991 [1973], p. 9), salientou Stephen Toulmin, que foi aluno de Wittgenstein em 1941 e em 1946-47. "Eu não consigo pensar em outra pessoa tão irascível" (PASCAL, 1984, p. 18), confessou Fania Pascal, que foi amiga e professora de russo de Wittgenstein. "Ele era um homem agressivo e explosivo, mas isso também de um jeito muito peculiar, ingênuo à sua maneira", completou (ibid., p. 47);

(5) seu egocentrismo e falta de empatia com as pessoas - "Ele nunca se via pelos olhos dos outros [...], ele não tinha outros padrões a não ser os seus", afirmou Pascal (ibid.). "Posso dizer a respeito de Wittgenstein que ele tinha todas as características de um profeta, mas nenhuma de discípulo" (MONK, 1995

SILVA, Gustavo Augusto Fonseca. A filosofia de Ludwig Wittgenstein à luz do diagnóstico de autismo. Griot : Revista de Filosofia, Amargosa - BA, v.19, n.1, p.226-253, fevereiro, 2019. 
[1990], p. 130), ironizou Max Bieler, que conheceu Wittgenstein durante a Primeira Guerra Mundial ${ }^{3}$;

(6) seus maneirismos e movimentos repetitivos - Franz Parak, por exemplo, que foi companheiro de prisão de Wittgenstein na Itália ao fim da Primeira Guerra Mundial, relatou que ele fazia um movimento característico com a cabeça, que normalmente ficava inclinada, mas era jogada para trás quando ele dirigia seu olhar ao longe (MCGUINNESS, 2005 [1988], p. 269). Além disso, há muitos registros de que os discípulos mais fervorosos de Wittgenstein chegavam a imitar seus gestos e suas expressões (e.g. GOLDESTEIN, 2008 [2005], p. 91 e MONK, 1995 [1990], p. 442);

(7) sua preferência por rotinas muito bem estabelecidas - "Ele era muito exigente e rigoroso, embora seus gostos fossem simples" (ibid., p. 505), disse a sra. Joan Bevan, que hospedou Wittgenstein em sua casa nas últimas semanas de vida do filósofo. "Era tácito que seu banho tinha de estar preparado no momento certo, que suas refeições fossem servidas no horário e que os eventos do dia transcorressem numa rotina regular";

(8) suas dificuldades de interação social - "(Wittgenstein) nem sempre se ajustava facilmente às convenções sociais", afirmou Russell em sua Autobiografia (II, p. 134). "Whitehead me descreveu a primeira visita que Wittgenstein lhe fez", lembrou Russell. "Recebido na sala de estar à hora do chá da tarde, pareceu não se dar conta da presença de Mrs. Whitehead. Passou algum tempo caminhando em silêncio de um lado para o outro da sala e por fim disse de chofre: 'Uma proposição tem dois polos. É $a p b$ '. 'Eu naturalmente perguntei o que são $a$ e $b$ ', contou-me Whitehead, 'mas percebi que tinha cometido um erro'. ' $a$ e $b$ são indefiníveis', respondeu Wittgenstein com voz de trovão" (ibid.);

(9) sua tendência de se isolar - "Ficar aqui (em Skjolden) sozinho me faz um bem incalculável e não creio que pudesse suportar viver entre as pessoas" (MONK, 1995 [1990], p. 98), admitiu Wittgenstein em carta a Russell de 1913. Colega de trabalho de Wittgenstein na Royal Victoria Infirmary, em Newcastle, durante a Segunda Guerra Mundial, a secretária Helen Andrews relatou que Wittgenstein "não se encaixava com facilidade" e preferia ficar sozinho em seu quarto em vez de se juntar aos colegas de trabalho com os quais estava hospedado (ibid., p. 400). Outro companheiro de trabalho de Wittgenstein na Royal Victoria Infirmary, o dr. E. G. Bywaters afirmou a seu respeito: "Ele era reservado e bastante retraído (...). Lembro-me dele como uma pessoa enigmática, pouco comunicativa e talvez um tanto deprimida, que preferia a cadeira de lona de seu quarto a qualquer encontro social" (ibid., p. 406);

Mais importante, porém, do que listar algumas das características de Wittgenstein que levaram psiquiatras contemporâneos a diagnosticá-lo postumamente como autista é explicitar o fato de que ele admiravelmente dedicou-se

\footnotetext{
3 Para uma reflexão sobre como o egocentrismo de Wittgenstein alicerça seu "método por exemplos" (WITTGENSTEIN, 1999 [1953], § 133), ver Silva (2018c).
}

SILVA, Gustavo Augusto Fonseca. A filosofia de Ludwig Wittgenstein à luz do diagnóstico de autismo. Griot : Revista de Filosofia, Amargosa - BA, v.19, n.1, p.226-253, fevereiro, 2019. 
por anos a tentar compreender e superar suas dificuldades comportamentais e cognitivas - acreditando que as demais pessoas também sofriam destas últimas.

\section{Processos interiores, critérios exteriores}

Segundo a psicóloga clínica infantil Chris Williams e o psiquiatra infantil Barry Wright, autores do manual Convivendo com autismo e síndrome de Asperger, indivíduos com distúrbios do espectro autista (Autistic Spectrum Disorder - ASD) apresentam grandes dificuldades de entender o ponto de vista, as ideias e os sentimentos de outras pessoas devido a sua "cegueira mental" (p. 35). Conforme Williams e Wright, a "cegueira mental" refere-se ao fato de indivíduos com ASD serem cegos em relação à mente de outras pessoas, um fenômeno que alguns pesquisadores denominam de "Teoria da Mente" insuficiente. Ainda de acordo com Williams e Wright, a Teoria da Mente (TOM) aborda a nossa habilidade de fazer suposições precisas sobre o que outros pensam, sentem e mesmo sobre o que farão, e a "cegueira mental" causa problemas justamente nessa habilidade, crucial para a vida em sociedade.

No caso de Wittgenstein, são abundantes não apenas as evidências de sua "cegueira mental", mas também suas reflexões sobre suas dificuldades de entender o ponto de vista, as ideias e os sentimentos de outras pessoas. No início dos anos 1930, por exemplo, Wittgenstein escreveu em seu caderno a respeito de sua amizade com G. E. Moore:

Tenho refletido algumas vezes acerca da minha estranha relação com
Moore. Eu o tenho em alta conta \& tenho por ele uma certa simpatia que
não é pequena. [...] ele é cordial comigo como o é com todos, \& se ele é
diferente com diferentes pessoas então não percebo a diferença pois são
justamente essas nuanças que não compreendo. [...] Ocorre, então, a
embaraçosa situação em que sentimos que nos impusemos às pessoas sem
que tenhamos querido ou sabido. De repente percebemos que as relações
que mantemos com elas não são as que supúnhamos, pois elas não
correspondem aos sentimentos que lhes dedicamos; mas não nos demos
conta, pois a diferença de papéis na relação é, em todo caso, tão grande
que pode facilmente esconder nuanças de simpatia \& antipatia
(WITTGENSTEIN, 2010a [1997], p. 47).

Sem compreender as nuanças de simpatia e antipatia de Moore, Wittgenstein recorrentemente impôs-se a ele ao longo de décadas de convivência sem que tivesse querido ou sabido. Em 1939, por exemplo, Moore leu um texto no Moral Science Club de Cambridge que depois foi duramente criticado em sua casa por Wittgenstein. Segundo Malcolm (1990 [1958], p. 43-44), na ocasião, Wittgenstein falou "rápida e energicamente" por pelo menos duas horas, não dando tempo a Moore para responder às suas objeções. Após alguns dias, porém, quando Yorick Smythies disse a Wittgenstein que ele havia sido rude com Moore, Wittgenstein considerou absurda sua asserção. Apesar disso, logo que se encontrou com Moore, Wittgenstein perguntou-lhe se havia sido de fato rude com ele em sua casa. Ante a confirmação de Moore, Wittgenstein desculpou-se formalmente.

SILVA, Gustavo Augusto Fonseca. A filosofia de Ludwig Wittgenstein à luz do diagnóstico de autismo. Griot : Revista de Filosofia, Amargosa - BA, v.19, n.1, p.226-253, fevereiro, 2019. 
Em outra reunião do Moral Science Club naquele ano, ainda de acordo com Malcolm, ele mesmo foi alvo da "intensidade" e "impaciência" de Wittgenstein (BOUWSMA, 2005 [1986], p. 45) depois de dizer a ele que sua crítica à apresentação de Moore não lhe parecia justa: "Ao fim da reunião", lembrou Malcolm (1990 [1958], p. 43), "e enquanto todos estavam de pé por ali, Wittgenstein caminhou até mim para me dizer, com os olhos soltando faíscas: 'Se soubesse algo, saberia que nunca fui injusto com ninguém. Isso prova que não entendeu absolutamente nada de minhas aulas'. Virou-se e se afastou. Fiquei pasmo". Mais tarde, depois de Smythies ter dito a Wittgenstein que ele também havia sido rude com Malcolm, Wittgenstein mais uma vez pediria desculpas ao amigo pelo ocorrido: "Smythies acha que não entendi o que você quis me dizer e, se é assim, desculpo-me" (ibid., p. 44).

Há muito familiarizada com a "selvageria incivilizada do estilo tirânico da argumentação de Wittgenstein”, como a denominou Ray Monk (1995 [1990], p. 236), a esposa de Moore teve de controlar suas visitas em 1944 para poupar o idoso e doente marido das exaustivas "discussões" com Wittgenstein ("ele discute", reclamou Moore em seu diário quando o visitou na Noruega, antes da Primeira Guerra Mundial (ibid., p. 103)). Mas, sem que tivesse querido ou sabido, Wittgenstein novamente se impôs ao amigo: "Moore gentil como sempre. Não pude ficar com ele muito tempo pois fomos interrompidos pela sra. Moore", escreveu Wittgenstein a Rush Rhees (ibid., p. 419-420). "Ela depois me disse que Moore na realidade não estava tão bem quanto aparentava e que não podia manter conversas demoradas. Tenho bons motivos para acreditar que isso é balela." De acordo com Monk (ibid., p. 420), Moore tinha sofrido um derrame nos Estados Unidos e sua esposa estava agindo segundo instruções médicas ao limitar suas conversas com os amigos filósofos, e Wittgenstein, em sua "inocência infantil" (PASCAL, 1984, p. 14), foi o único que achou ruim. "Ele não percebia o quanto podia ser fatigante, a tal ponto que em pelo menos uma ocasião Moore pediu-me de antemão: 'Não o deixe ficar muito tempo"”, disse a sra. Moore (MONK, 1995 [1990], p. 420).

Dada a sua "cegueira mental", Wittgenstein tampouco percebia as nuanças de simpatia e antipatia das pessoas por quem se apaixonava. Assim, no fim de 1929, Wittgenstein também se impôs sem que tivesse querido ou sabido à jovem Marguerite Respinger, com quem queria se casar. Conforme Monk (ibid., p. 258), Wittgenstein não percebeu o que estava sendo insinuado quando ela lhe disse que não queria mais beijá-lo. Além disso, ainda de acordo com Monk, em seu diário, Wittgenstein não reflete sobre os sentimentos dela, mas apenas sobre os seus. Anos mais tarde, em 1941, pouco depois da morte de seu companheiro Francis Skinner, Wittgenstein daria novas mostras de sua incapacidade de entender o ponto de vista ou as ideias e sentimentos de outras pessoas. Naquele período, Wittgenstein escreveu a Rowland Hutt dizendo que achava que Skinner tinha tido "uma das vidas mais felizes" que tinha conhecido (ibid., p. 381), claramente sem ter percebido, ou sem ter considerado, o quanto Skinner era infeliz no trabalho braçal a que havia se submetido por sua influência e, sobretudo, o quanto era infeliz por ter sido privado da sua presença e do seu afeto (cf. MONK, 1995 [1990], p. 323-326 e p. 379). Na verdade, Wittgenstein não se importava com o que pensava ou sentia a pessoa amada, como observa Monk (ibid., p. 382) ao comentar sua paixão por David 
Pinsent, por Marguerite Respinger e especialmente por Keith Kirk, um jovem que lhe havia sido apresentado pelo próprio Skinner:

\begin{abstract}
As observações em código [dos diários de Wittgenstein] (...) revelam o grau em que a vida amorosa e sexual de Wittgenstein acontecia apenas na sua imaginação. $O$ caso mais impressionante é o de Keith Kirk, por quem Wittgenstein teve uma breve obsessão (...), mas é algo evidente em quase todas as suas relações íntimas. A maneira como Wittgenstein via e vivia uma relação muitas vezes nada tinha a ver com a maneira como era vista e vivida pela outra pessoa. Se eu não houvesse conhecido pessoalmente Keith Kirk, e me baseado apenas nas observações em código, teria quase certeza que ele e Wittgenstein haviam tido alguma espécie de "caso". No entanto, como tive a oportunidade de conhecê-lo, estou certo que qualquer caso que possa ter havido existiu apenas na mente de Wittgenstein (ibid., p. 515).
\end{abstract}

À luz do diagnóstico póstumo de autismo, mudam de aspecto os comentários de Monk sobre o "relacionamento" entre Wittgenstein e Kirk, bem como sua afirmação de que "o solipsismo filosófico pelo qual em certa época (Wittgenstein) se sentira atraído e contra o qual boa parte de sua obra madura é dirigida [...] encontra paralelo no solipsismo emocional de suas ligações românticas" (ibid., p. 382). Também muda de aspecto, à luz do diagnóstico póstumo de autismo, a afirmação de Fania Pascal de que não se podia imaginar Wittgenstein "necessitando de expressão física normal de afeto" (1984, p. 48) - algo que o próprio Wittgenstein reconheceu: "Ainda que não possa dar afeto, tenho uma grande necessidade dele" (MALCOLM, 1990 [1958], p. 66), disse em determinada ocasião. Mas mais importante: à luz do diagnóstico póstumo de autismo, muda de aspecto o fato de que Wittgenstein tenha refletido por anos a respeito dos olhos e dos olhares das pessoas, sobre os quais escreveu, por exemplo:

Interpreto palavras; sim - mas também interpreto olhares? Interpreto
uma expressão facial como sendo ameaçadora ou simpática? - Isto pode
acontecer.
Supõe que digo: "Não chega perceber a face ameaçadora, tenho de
interpretá-la". - Alguém empunha uma faca na minha direção, e eu digo
"Entendo isto como uma ameaça" (WITTGENSTEIN, 1992b [1967], §
218).
Faz com que um ser humano lance olhares zangados, orgulhosos, irônicos;
e agora tapa-lhe o rosto de forma a que só os olhos fiquem a descoberto -
nos quais toda a expressão parecia estar concentrada: a sua expressão é
agora surpreendentemente ambígua (ibid., §224).

À luz do diagnóstico póstumo de autismo, muda de aspecto na verdade o fato de que Wittgenstein tenha refletido tanto sobre o comportamento humano e sobre as expressões faciais de modo geral (e.g. WITTGENSTEIN, 1992c [1958], I, § 48; II, § 7; WITTGENSTEIN, 1999 [1953], §§ 285, 357, 536, 537, 539, 543, 652; WITTGENSTEIN, 2008a [1980], I, §§ 137-138), ciente de que "um "processo interior' necessita critérios exteriores" (WITTGENSTEIN, 1999 [1953], § 580):

SILVA, Gustavo Augusto Fonseca. A filosofia de Ludwig Wittgenstein à luz do diagnóstico de autismo. Griot : Revista de Filosofia, Amargosa - BA, v.19, n.1, p.226-253, fevereiro, 2019. 


\begin{abstract}
A consciência no rosto do outro. Olha para o rosto do outro e vê nele a consciência, um cambiante específico de consciência. Vês nele alegria, indiferença, interesse, excitação, apatia, etc. A luz no rosto do outro. Olhas para dentro de $t i$, para reconheceres a fúria no rosto dele? Está lá, tão claramente como dentro do teu próprio peito (WITTGENSTEIN, 1992b [1967], § 220).

A consciência é tão nítida no seu rosto e comportamento, como em mim mesmo (ibid., § 221).
\end{abstract}

E, ao refletir sobre os critérios exteriores de um "processo interior", tendo como modelo o starets Zosima (MONK, 1995 [1990], p. 482), personagem de Os irmãos Karamazov que só de ver o rosto das pessoas que o procuravam já sabia o que as atormentava, Wittgenstein privilegiava a dor em relação a outros sentimentos e sensações (e.g. WITTGENSTEIN, 1992b [1967], §§ 225, 504 e WITTGENSTEIN, 1999 [1953], §§ 302-303) porque, "se vejo alguém se torcer de dor, com uma causa evidente, não penso: seus sentimentos estão ocultos para mim" (ibid., II, XI). "Realmente", bem ponderou A. J. Ayer (1985, p. 77), "a preferência de Wittgenstein pela dor como um exemplo sem dúvida se deve ao fato de que ela é caracteristicamente associada a um conjunto claramente limitado de expressões externas; algo que não é verdade sobre todas as sensações, menos ainda pensamentos e imagens." Muito menos nuanças de simpatia e antipatia das pessoas.

\title{
Um estilo irremediavelmente desastrado
}

Outra particularidade de indivíduos com ASD, segundo Williams e Wright (2008 [2003], p. 43), é a enorme dificuldade que eles têm de reunir informações para entender a essência do que está acontecendo ou o que se espera deles. Se ouvirmos os sinos da igreja badalando e vermos pessoas em roupas formais jogando confete em um casal, exemplificam os especialistas, concluiremos que se trata de um casamento. Já alguém com ASD talvez se concentre em algum detalhe dessa situação, como os sinos badalando, sem perceber que se trata de um casamento. Essa limitação, observam Williams e Wright, estende-se à compreensão de figuras, histórias, eventos e objetos, bem como ao uso da linguagem:

\footnotetext{
Para crianças com dificuldades relacionadas ao espectro do autismo, sua própria linguagem pode parecer tão confusa quanto os idiomas estrangeiros para a maioria das pessoas. Quase sempre isso acontece porque elas se esforçam muito para entender a essência da situação, visto que não conseguem entender o significado de palavras dentro do contexto correto. Por exemplo:

Uma mãe comentou: “Oh, meu Deus, meu pé está molhado. Deve ter um furo na minha bota". A filha insistiu que a mãe tirasse a bota e o furo. Nesse caso, a criança não conseguiu usar o contexto para entender que o furo que a mãe mencionou não era um objeto removível.

Uma avó relatou que disse à neta que gostava de enfiar os "pés grandes" na água morna. A neta ficou assustada e inquieta, insistindo em verificar se a avó não tinha, subitamente, adquirido pés como o do Pé Grande em seu livro de história (ibid., p. 44).
}

SILVA, Gustavo Augusto Fonseca. A filosofia de Ludwig Wittgenstein à luz do diagnóstico de autismo. Griot : Revista de Filosofia, Amargosa - BA, v.19, n.1, p.226-253, fevereiro, 2019. 
Já Monk (1995 [1990], p. 154) relatou que, quando Wittgenstein era prisioneiro de guerra em Cassino, na Itália, em 1919, um parente com influências no Vaticano tentou libertá-lo enviando ao local um médico que o examinaria e o declararia incapaz de suportar o confinamento prolongado. Wittgenstein, no entanto, rejeitou esse tratamento privilegiado, insistindo durante o exame que gozava de perfeita saúde. Ou melhor, à luz do diagnóstico póstumo de autismo: com sua dificuldade em entender a essência da situação, Wittgenstein, em sua "ingenuidade" (PASCAL, 1984, p. 27 e p. 47), provavelmente não percebeu a real intenção do médico.

O filósofo John Mabbott, por sua vez, relatou que, ao chegar a Nottingham para participar de um simpósio de que Wittgenstein também participaria, encontrou-se no albergue com um homem de aparência juvenil de mochila, calção e camisa aberta no peito (MONK, 1995 [1990], p. 252). Conforme Monk, por não conhecer Wittgenstein pessoalmente, Mabbott supôs que ele fosse algum estudante de férias que não sabia que o albergue havia sido reservado para os participantes do simpósio. "Temo que esteja acontecendo um encontro de filósofos aqui", disse Mabbott a Wittgenstein, que lhe respondeu "sombriamente": "Eu também". E temo que Wittgenstein, com sua dificuldade em entender a essência da situação, não tenha percebido a suposição que Mabbott havia feito.

Esposa do dr. Edward Bevan, a sra. Bevan relatou a Monk (ibid., p. 505) que foi precavida pelo marido que Wittgenstein não gostava de "conversa fiada" e por isso deveria ser cuidadosa para não dizer nada leviano com o novo hóspede. Assim, no jantar de apresentação, a sra. Bevan preferiu permanecer em silêncio, até que Wittgenstein mencionou sua estada em Ithaca, nos Estados Unidos, ao que ela teria dito, jovialmente: “Que sorte a sua ir para os Estados Unidos!". Segundo Monk, "Wittgenstein fixou seus olhos nos dela e perguntou: 'O que a senhora quer dizer com sorte?"', obviamente sem entender a essência da situação. A sra. Bevan também relatou a Monk (ibid., p. 507) que, no $62^{\circ}$ aniversário de Wittgenstein - que àquela altura tinha câncer na próstata em estágio terminal -, deu-lhe de presente um cobertor elétrico e desejou-lhe "muitos anos de vida", ao que Wittgenstein "olhou duro para ela e respondeu: "Não haverá mais anos de vida"”.

Tendo em vista relatos como os da sra. Bevan, David Edmonds e John Eidinow concluíram: "Não se tratava apenas de maneiras inadequadas ou de um estilo irremediavelmente desastrado. Wittgenstein não pertencia ao mundo da conversa educada e do bate-papo social. Clareza de sentido era tudo, e ele ia direto ao ponto - não importava o quê" (EDMONDS; EIDINOW, 2003 [2001], p. 208). Ou melhor, à luz do diagnóstico póstumo de autismo: dada a enorme dificuldade que Wittgenstein tinha de reunir informações para entender a essência do que estava acontecendo ou o que se esperava dele, isto é, dadas as suas "dificuldades pragmáticas de linguagem" (WILLIAMS; WRIGHT, 2008 [2003], p. 21), Wittgenstein não conseguia pertencer ao mundo da conversa educada e do bate-papo social, como relatou a filósofa e escritora Iris Murdoch, que assistiu a algumas de suas aulas em Cambridge:

O caráter extraordinariamente direto de sua abordagem e a ausência de qualquer espécie de parafernália eram coisas que enervavam as pessoas.

SILVA, Gustavo Augusto Fonseca. A filosofia de Ludwig Wittgenstein à luz do diagnóstico de autismo. Griot : Revista de Filosofia, Amargosa - BA, v.19, n.1, p.226-253, fevereiro, 2019. 
Para a maioria das pessoas, um relacionamento se dá em determinado contexto e existem certas convenções acerca de como conversar, e assim por diante. Não há um confronto nu e cru de personalidades. Mas Wittgenstein sempre impunha esse confronto em todos os seus relacionamentos. Eu o encontrei apenas duas vezes e não cheguei a conhecê-lo bem; talvez por isso sempre o tenha considerado, enquanto pessoa, com pasmo e inquietação (MONK, 1995 [1990], p. 440-441).

Dolorosamente ciente de que suas maneiras inadequadas enervavam as pessoas e geravam mal-entendidos, Wittgenstein lamentou em seu caderno no início dos anos 1930:

\begin{abstract}
Quando a gente conversa com pessoas que realmente não compreendem a gente sente sempre que has made fool of oneself, pelo menos eu. E isso sempre volta a acontecer comigo. Temos a escolha entre o estranhamento total e essa experiência desagradável. E eu poderia de fato dizer: Tenho também aqui (em Cambridge) uma ou outra pessoa com a qual posso conversar sem correr esse risco; \& por que não me afasto totalmente das outras? Mas isso é difícil \& antinatural para mim. A dificuldade reside em conversar amigavelmente com uma pessoa sem tocar em pontos que possam gerar mal-entendidos. Conversar seriamente \& de tal modo que não se toque em coisas irrelevantes que possam conduzir a mal-entendidos. Isso me é quase impossível (WITTGENSTEIN, 2010a [1997], p. 52).
\end{abstract}

No mesmo período, Wittgenstein também se queixou em seu caderno: “[...] sou obrigado a viver com pessoas às quais não posso me fazer compreender. - Este é um pensamento que eu realmente tenho com frequência. Mas ao mesmo tempo a sensação de que é minha própria culpa" (MONK, 1995 [1990], p. 253). Assim, por um lado, Wittgenstein via-se obrigado a viver com pessoas às quais não podia se fazer compreender, tendo a sensação de que era sua própria culpa. Por outro, as pessoas com as quais convivia o consideravam com pasmo e inquietação. Nessas circunstâncias, que mudam de aspecto considerando-se o diagnóstico póstumo de autismo, não espanta que Wittgenstein recorrentemente reclamasse de ser incompreendido. Nem espanta que Wittgenstein tenha escrito já ao fim da vida: "Numa conversa: uma pessoa atira a bola; a outra não sabe se deve atirá-la de volta ou atirá-la a uma terceira pessoa, ou deixá-la no chão, ou apanhá-la e pô-la no bolso, etc." (WITTGENSTEIN, 1992a [1958], p. 110).

\title{
Uma maneira de olhar para o mundo
}

De acordo com Williams e Wright (2008 [2003], p. 64-66), pessoas com ASD também tendem a apresentar problemas com a imaginação. Como consequência disso, o senso de humor delas é afetado, já que grande parte do humor envolve a imaginação, com exceção às palhaçadas. Uma piada simples como "Por que a galinha atravessou a rua?", exemplificam Williams e Wright, nos leva a pensar em muitas possibilidades antes de ouvir a resposta óbvia: "Para chegar ao outro lado da rua". Segundo os autores, "achamos engraçado porque nossa imaginação procura todos os tipos de alternativas antes de ouvir a resposta óbvia. Fomos comicamente

SILVA, Gustavo Augusto Fonseca. A filosofia de Ludwig Wittgenstein à luz do diagnóstico de autismo. Griot : Revista de Filosofia, Amargosa - BA, v.19, n.1, p.226-253, fevereiro, 2019. 
enganados. Indivíduos com ASD não acham graça porque não passam pelo processo imaginativo. Para chegar ao outro lado? Claro! Que graça tem isso?" (ibid., p. 66).

Em se tratando de Wittgenstein, não faltam testemunhos de seu "humor um tanto lento", como o definiu David Pinsent (BUCHHOLZ, 2009, p. 40), basicamente restrito àquilo que o próprio Wittgenstein denominou de nonsense (MONK, 1995 [1990], p. 244). "Se por senso de humor nós nos referimos à capacidade de nos ver no ato de lidar com os outros", afirmou Fania Pascal (1984, p. 33), "então Wittgenstein carecia dele inteiramente." Na verdade, segundo Monk (1995 [1990], p. 244), Wittgenstein sentia necessidade de "falar besteiras pelo cotovelo" e, nos anos 1930, encontrou em Gilbert Pattisson a pessoa certa para isso. Dado revelador, que muda de aspecto à luz do diagnóstico póstumo de autismo, na opinião de Monk (ibid., p. 245), "algumas das piadas contidas nas cartas de Wittgenstein a Pattisson são espantosamente fracas":

\begin{abstract}
Ao incluir um endereço que terminava "W.C.1" [Western Central, distrito postal de Londres], ele rabiscou uma seta apontando para o "W.C." e escreveu: "Isto não significa banheiro". E no verso de um cartão-postal da catedral Christ Church de Dublin escreveu: "Se bem me lembro, esta catedral foi construída, em parte ao menos, pelos normandos. Naturalmente, foi há muito tempo e a minha memória já não é tão boa quanto na época" (ibid.).
\end{abstract}

Em vista do humor "insípido e banal" de Wittgenstein, como o descreveu Frances Partridge (ibid., p. 244), e de sua preferência pelo nonsense, não surpreende que ele julgasse de mau gosto a ironia socrática: "Por que não poderá um homem ir direto ao assunto e dizer o que tem em mente?" (BOUWSMA, 2005 [1986], p. 106). Nem surpreende que Wittgenstein tanto refletisse sobre o humor e sobre a maneira como as pessoas interagem, conforme ilustram estes exemplos:

O humor não é uma disposição, mas uma maneira de olhar para o mundo (WITTGENSTEIN, 1992a [1958], p. 114).

Duas pessoas riem juntas, digamos, de uma anedota. Uma delas utilizou certas palavras um tanto fora do vulgar e agora ambas irrompem numa espécie de balidos. Isso poderia parecer muito extraordinário a um visitante que viesse de um meio totalmente diferente. Para nós, porém, é inteiramente aceitável.

(Testemunhei recentemente esta cena num autocarro e consegui pôr-me na posição de alguém a quem isto não fosse familiar. A cena impressionou-me como se fosse totalmente irracional e como as respostas de um animal estranho.) (ibid., p. 114-115)

Que acontece quando as pessoas não têm o mesmo sentido de humor? Não reagem umas às outras convenientemente. É como se entre certos homens existisse o costume de um atirar a outro uma bola, que deve ser por este agarrada e atirada de volta; mas alguns, em vez de a atirarem de volta, põem-na nos seus bolsos [...] (ibid., p. 121).

Devido a sua ausência de imaginação, Wittgenstein não tinha o mesmo sentido de humor que as demais pessoas e não reagia a elas convenientemente, como revelado por Bouwsma (2005 [1986], p. 51) em mais um episódio de Wittgenstein que muda de aspecto considerando-se o diagnóstico póstumo de autismo:

SILVA, Gustavo Augusto Fonseca. A filosofia de Ludwig Wittgenstein à luz do diagnóstico de autismo. Griot : Revista de Filosofia, Amargosa - BA, v.19, n.1, p.226-253, fevereiro, 2019. 
Desci a rua ao seu encontro e depressa o vi aparecer à esquina com a sua bengala e um passo desajeitado, rígido, mas bastante vigoroso ao mesmo tempo. Cumprimentei-o, dizendo-lhe que parecia um bom andarilho; e é curioso como ele considera seriamente os gracejos desse gênero. $\mathrm{Oh}$, não. De maneira nenhuma, ele era aquilo a que se pode chamar um bom andarilho, etc.

Na introdução ao livro de Bouwsma (p. 24), J. L. Craft e Ronald E. Hustwit comentam o ocorrido:

O espírito de Wittgenstein está sempre a trabalhar e a trabalhar exigentemente - até mesmo no que se refere às pequenas coisas. À observação de Bouwsma segundo a qual Wittgenstein é um bom andarilho, o segundo replica que de maneira nenhuma o é. Mas não é como se estivesse deliberadamente a tentar mostrar-se difícil; limita-se, pelo contrário, a tomar a sério as palavras ocasionais de Bouwsma.

Ou melhor, à luz do diagnóstico póstumo de autismo: o episódio é mais uma evidência de que a ausência de imaginação decorrente de ASD deixou Wittgenstein "com maneiras predominantemente lógicas, fixas, concretas e literais de falar e pensar" (WILLIAMS; WRIGHT, 2008 [2003], p. 67).

\section{Um entendimento literal}

Dada a sua ausência de imaginação e suas maneiras predominantemente lógicas, fixas, concretas e literais de falar e pensar, Wittgenstein não apenas não tinha o mesmo sentido de humor que as demais pessoas como tendia a ter um entendimento literal de metáforas, analogias e expressões idiomáticas, como costuma acontecer com indivíduos com ASD (WILLIAMS; WRIGHT, 2008 [2003], p. 67 e p. 75). Não por acaso, Wittgenstein - que afirmaria que "a filosofia explicita as analogias enganadoras no uso de nossa linguagem" (WITTGENSTEIN, 2005b, § 87) - apreciava o posfácio que Paul Ernst escreveu para a sua edição dos Contos de Grimm porque nele, segundo a leitura distorciva de Wittgenstein, Ernst faz indicações sobre como a linguagem nos conduz ao engano por meio de metáforas que são interpretadas literalmente (MCGUINNESS, 2005 [1988], p. 251-252). Tampouco por acaso, aproximadamente no mesmo período em que descobriu o texto de Ernst, durante a Primeira Guerra Mundial, Wittgenstein preferia interpretar metáforas com o amigo Max Bieler a interpretá-las sozinho (ibid., p. 236). Anos mais tarde, ainda ocupado com os problemas decorrentes de entender metáforas e analogias literalmente, Wittgenstein alertaria nas Investigações filosóficas: “[...] o emprego figurado da palavra não pode entrar em conflito com o emprego original" (II, XI). O próprio Wittgenstein, no entanto, por motivos que agora compreendemos, frequentemente levava o emprego figurado de uma palavra ou de uma expressão a entrar em conflito com o emprego original, como atesta o relato de Fania Pascal a respeito da visita que Wittgenstein lhe fez no hospital após ela ter passado por uma cirurgia:

SILVA, Gustavo Augusto Fonseca. A filosofia de Ludwig Wittgenstein à luz do diagnóstico de autismo. Griot : Revista de Filosofia, Amargosa - BA, v.19, n.1, p.226-253, fevereiro, 2019. 
Extraí as amígdalas e jazia no hospital Evelyn Nursing Home com pena de mim mesma. Wittgenstein veio me visitar. Reclamei: "Sinto-me como um cão que foi atropelado". Ele se indignou: "Você não sabe como se sente um cão que foi atropelado" (GOLDESTEIN, 2008 [2005], p. 96).

Segundo Goldstein (ibid.), o episódio é prova de que a austeridade lógica de Wittgenstein "se aplicava à pessoa também, como se a pureza da lógica formal tivesse se corporificado no homem, seus padrões de verdade absoluta impostos ao comportamento humano". Ou melhor, à luz do diagnóstico póstumo de autismo: o episódio é prova de que a ausência de imaginação decorrente de ASD deixou Wittgenstein com maneiras predominantemente lógicas, fixas, concretas e literais de falar e pensar. Maneiras que marcaram profundamente as reflexões de Wittgenstein sobre a linguagem.

\title{
As disformidades do pensamento de Wittgenstein
}

Convencido de que "os problemas filosóficos nascem quando a linguagem entra em férias" (WITTGENSTEIN, 1999 [1953], § 38) e que, portanto, "a filosofia é uma luta contra o enfeitiçamento do nosso entendimento pelos meios da linguagem" (ibid., § 109), Wittgenstein é taxativo:

\begin{abstract}
Nossa consideração é [...] gramatical. E esta consideração traz luz para o nosso problema, afastando os mal-entendidos. Mal-entendidos que concernem ao uso das palavras; provocados, entre outras coisas, por certas analogias entre as formas de expressão em diferentes domínios da nossa linguagem. Muitos deles são afastados ao se substituir uma forma de expressão por outra; isto pode chamar de "análise" de nossas formas de expressão, pois esse processo assemelha-se muitas vezes a uma decomposição (ibid., §90).
\end{abstract}

A consideração de Wittgenstein é gramatical. Mas esta consideração de fato traz luz para o nosso problema, afastando os mal-entendidos? E os mal-entendidos de Wittgenstein que concerniam ao uso das palavras são os nossos mal-entendidos? "Quando as palavras na nossa linguagem vulgar têm, à primeira vista, gramáticas análogas, tendemos a tentar interpretá-las de modo análogo; isto é, tentamos manter a analogia a qualquer preço", afirma Wittgenstein no Livro azul (p. 30). No próprio Livro azul (p. 62), Wittgenstein dá exemplos esclarecedores de palavras na nossa linguagem vulgar que, por terem, à primeira vista, gramáticas análogas supostamente foram interpretadas de modo análogo pelos matemáticos:

[...] podemos dizer de alguns matemáticos com inclinações filosóficas que eles não estão evidentemente cientes da diferença existente entre os muitos diversos usos da palavra "demonstração"; e que eles não clarificaram a diferença entre os usos da palavra "espécie", quando falam de espécies de números, espécies de demonstrações, como se a palavra "espécie" significasse aqui o mesmo que no contexto "espécies de maçãs". Ou podemos dizer que eles não têm conhecimento dos diferentes sentidos da palavra "descoberta", quando num caso falamos da descoberta da construção do pentágono e, num outro caso, da descoberta do Polo Sul.

SILVA, Gustavo Augusto Fonseca. A filosofia de Ludwig Wittgenstein à luz do diagnóstico de autismo. Griot : Revista de Filosofia, Amargosa - BA, v.19, n.1, p.226-253, fevereiro, 2019. 
E podemos dizer de Wittgenstein que ele, caracteristicamente sem identificar os alvos de seus ataques, estendeu aos matemáticos seus mal-entendidos que concerniam ao uso das palavras, provocados, entre outras coisas, por certas analogias entre as formas de expressão em diferentes domínios da nossa linguagem, acreditando que os matemáticos não estavam cientes da diferença existente entre os muitos diversos usos da palavra "demonstração"; e que eles não clarificaram a diferença entre os usos da palavra "espécie", quando falavam de espécies de números, espécies de demonstrações, espécies de maçãs. E ainda que eles não tinham conhecimento dos diferentes sentidos da palavra "descoberta", quando num caso falavam da descoberta da construção do pentágono e, num outro caso, da descoberta do Polo Sul. Esta última provavelmente uma consideração gramatical sobre a velha analogia feita pelos matemáticos entre uma descoberta matemática e a descoberta de um continente. Uma analogia feita recentemente, por exemplo, pelo matemático de Oxford Marcus du Sautoy no primeiro episódio da série de TV $A$ história da matemática, produzida pela $\mathrm{BBC}$ há alguns anos, em referência à descoberta pelos pitagóricos dos números irracionais: "A descoberta deste novo número e de outros como ele é semelhante a um explorador que descobre um novo continente ou a um biólogo que encontra uma nova espécie", disse o professor Du Sautoy. Não por coincidência, a mesma analogia foi feita pelo matemático Wu Yi Hsiang no livro $A$ concise introduction to calculus: "A descoberta de Hipaso de pares de intervalos não comensuráveis demonstrou a existência de números irracionais, que pode ser comparada com a descoberta de um novo continente na matemática" (p. 17).

A velha analogia feita pelos matemáticos entre uma descoberta matemática e a descoberta de um continente possivelmente tenha levado Wittgenstein a explicitar os diferentes sentidos da palavra "descoberta" e a criticar com Friedrich Waismann a concepção que Gottlob Frege tinha dos números: "Ele pensa que os números já estão lá de alguma maneira, de modo que a descoberta dos números imaginários é comparável, digamos, à descoberta de um continente desconhecido" (WITTGENSTEIN; WAISMANN, 2003, p. 153). Frege realmente pensava que os números já estão lá de alguma maneira, cabendo ao matemático descobri-los, e não inventá-los, como explicitou no $\S 96$ dos Fundamentos da aritmética: “(...) o matemático nada pode criar arbitrariamente, não mais do que o geógrafo; também ele apenas pode descobrir o que há e nomeá-lo". Russell igualmente pensava que os números já estão lá de alguma maneira, cabendo ao matemático descobri-los, e não inventá-los, conforme argumentou no $§ 427$ dos Principles of mathematics: “(...) a aritmética deve ser descoberta exatamente no mesmo sentido em que Colombo descobriu as Índias Ocidentais, e nós não mais criamos os números do que ele criou os índios". Muitos séculos antes de Frege e de Russell, o platônico Santo Agostinho, que Wittgenstein tanto admirava (DRURY, 1984a, p. 90), já defendia a ideia de que os números já estão lá de alguma maneira, cabendo ao matemático descobri-los, e não inventá-los, como afirmou na Doutrina cristã (II, 39, 56):

Quanto à ciência dos números, é evidente - até para todos os espíritos, inclusive os mais lentos - que ela não foi inventada pelos homens, mas apenas procurada e descoberta por eles. Pois com ela não acontece como se deu com a primeira sílaba da palavra Itália, que os antigos pronunciavam

SILVA, Gustavo Augusto Fonseca. A filosofia de Ludwig Wittgenstein à luz do diagnóstico de autismo. Griot : Revista de Filosofia, Amargosa - BA, v.19, n.1, p.226-253, fevereiro, 2019. 
breve, mas que se tornou longa pela vontade de Virgílio. Não está no poder de ninguém, a seu bel-prazer, fazer que três vezes três sejam nove; que nove não possa formar um quadrado; que esse número contenha uma vez e meia seis; que não possa ser o duplo de um número inteiro, já que os números ímpares não se dividem por dois.

Seja, pois, que se considerem as leis numéricas em si próprias, seja que se utilizem como leis da geometria ou da música ou de outros movimentos, elas sempre têm regras imutáveis, que não foram de modo algum inventadas pelos homens, mas sim descobertas pela sagacidade de espíritos engenhosos.

Mas o fato de Santo Agostinho, Frege e Russell, como tantos outros filósofos e matemáticos, pensarem que os números são descobertos, e não inventados, evidentemente não significa que eles não tinham conhecimento dos diferentes sentidos da palavra "descoberta", quando num caso falavam de uma descoberta matemática e, num outro caso, de uma descoberta geográfica. Prova disso é que no prefácio de Introduction to mathematical thinking, livro em que a crítica de Wittgenstein e de Waismann a Frege é reproduzida (p. 241-242), Waismann recorre justamente à analogia entre uma descoberta matemática e uma descoberta geográfica - sem mal-entendido algum, é claro:

Procedendo de pontos de vista intuitivos, Leibniz e Newton criaram o cálculo diferencial e integral. No século 18, essas investigações se elevaram extraordinariamente, uma descoberta brilhante seguindo-se à outra na esfera da análise pura assim como no domínio de suas aplicações. Esse período da matemática foi comparado, não injustamente, com o período das grandes descobertas e dos heróis do mar. Os matemáticos daquele período tinham a sensação de estar pisando em um novo mundo intelectual, ávidos em explorar os contornos do continente que se abria para eles da neblina.

Por motivos que agora compreendemos, uma analogia entre formas de expressão em diferentes domínios da nossa linguagem levava Wittgenstein a achar importante explicitar os diferentes sentidos de uma palavra, como o fez em uma aula no início dos anos 1930, na qual disse aos alunos:

"Procurar" tem dois significados diferentes em frases como "procurar
alguma coisa no Polo Norte", "procurar a solução de um problema"4. Uma
diferença entre uma expedição de descoberta ao Polo Norte e uma
tentativa de encontrar uma solução matemática é que na primeira é
possível descrever de antemão o que está sendo procurado, enquanto na
matemática quando você descreve a solução você fez a expedição e
encontrou o que você procurava. A descrição da prova é a própria prova,
enquanto achar a coisa no Polo Norte [não é o suficiente descrevê-la]. Você
deve fazer a expedição (WITTGENSTEIN, 2001, p. 7).

Mas essa consideração gramatical de Wittgenstein esclarece algo aos matemáticos? Essa consideração gramatical de Wittgenstein nos esclarece algo?

\footnotetext{
${ }^{4}$ No original, "to look for", "to look for something at the North Pole" e "to look for a solution to a problem", respectivamente.
}

SILVA, Gustavo Augusto Fonseca. A filosofia de Ludwig Wittgenstein à luz do diagnóstico de autismo. Griot : Revista de Filosofia, Amargosa - BA, v.19, n.1, p.226-253, fevereiro, 2019. 
Em outra aula do início dos anos 1930, Wittgenstein disse ainda aos alunos sobre o verbo "procurar":

[...] há muitos processos diferentes que chamamos de "procurar em nossa memória". A última frase é um símile tomado de "procurar em um quarto"s. Obviamente, procurar em um quarto é diferente de procurar na memória. Há a possibilidade de cobrir a área no primeiro caso, então, se o que é solicitado está lá, vai-se achá-lo. Além disso, nós podemos dizer de procurar em um quarto que a coisa solicitada está lá ou não. Mas isso não pode ser dito da memória. Procurar na memória é comparável a depender de um mecanismo que ou faz ou não faz o trabalho, como apertar uma linha de botões, nenhum dos quais pode fazer soar o sino (ibid., p. 54-55).

Mas a quem seria necessário esclarecer que "procurar em um quarto é diferente de procurar na memória"? A quem seria necessária toda essa consideração gramatical? "A dificuldade é que nossa linguagem usa cada uma das palavras 'pergunta', 'problema', 'investigação', 'descoberta' para referir-se a coisas essencialmente diferentes. O mesmo ocorre com "inferência', "proposição", "prova" (WITTGENSTEIN, 2005a [1964], p. 158). E o mesmo ocorre com "demonstração", "espécie", "procurar"... Mas a quem isso poderia causar tanta dificuldade? Podemos dizer que, por motivos que agora compreendemos, o que era difícil para Wittgenstein, o que o confundia, era a uniformidade da aparência das palavras, quando estas lhe eram ditas, ou quando com elas se defrontava na escrita e na imprensa. Pois seu emprego não lhe era tão claro. E especialmente não o era quando filosofava. Por isso, Wittgenstein achava importante explicitar os diferentes sentidos de uma palavra e as diferenças entre espécies de palavras, como o fez no $§ 10$ das Investigações filosóficas:

[...] pode-se dizer que os signos a, b etc. designam números; se isto talvez suprimir o mal-entendido de crer que $a, b$, c desempenhariam na linguagem o papel que, na realidade, "cubos", "lajotas", "colunas" desempenham. E, pode-se também dizer, "c" designa este número e não aquele; se com isso se pode explicar que as letras deveriam ser empregadas na sequência $a, b, c, d$ etc., e não nesta: $a, b, d, c$.

Mas pelo fato de que se assimilam assim as descrições do uso das palavras umas com as outras, este uso não pode, no entanto, tornar-se mais semelhante! Pois, como vimos, ele é totalmente dissemelhante.

Mas quem poderia crer que $a, b$, c desempenhariam na linguagem o papel que, na realidade, "cubos", "lajotas", "colunas" desempenham? A quem poderia ser importante ensinar que o uso dos substantivos "cubos", "lajotas", "colunas" é totalmente dissemelhante do uso dos numerais $a, b, c, d$ ?

Ainda ocupado com numerais, Wittgenstein explicita mais à frente nas Investigações filosóficas os diferentes sentidos de "1":

O que acontece quando pergunto: é-nos claro, enquanto pronunciamos as frases "este bastão tem 1 metro de comprimento" e "aqui está 1 soldado",

5 No original, "looking in our memory" e "looking in a room", respectivamente.

SILVA, Gustavo Augusto Fonseca. A filosofia de Ludwig Wittgenstein à luz do diagnóstico de autismo. Griot : Revista de Filosofia, Amargosa - BA, v.19, n.1, p.226-253, fevereiro, 2019. 
que queremos dizer com "l" coisas diferentes, que "l" tem diferentes significações? - De nenhum modo.

- Diga, por exemplo, uma frase como "a cada 1 metro está um soldado, a cada 2 metros, portanto, 2 soldados". À questão: "Você quer dizer o mesmo com ambos os "um'?", responderíamos, por exemplo: “Na verdade, quero dizer o mesmo: um!" (E nisto levantamos um dedo, por exemplo.) (§ $552)$

Ora, o "1" tem significação diferente ao designar ora a medida, ora a quantidade? Se a questão foi colocada assim, a resposta será: sim (§ 553).

E, se a questão foi colocada assim por Wittgenstein, afasta algum malentendido dos matemáticos? Se a questão foi colocada assim por Wittgenstein, afasta algum mal-entendido nosso? "Eu não devia ser mais do que um espelho em que o meu leitor pudesse ver o seu próprio pensamento com todas as suas disformidades para que, assim auxiliado, o pudesse pôr em ordem" (WITTGENSTEIN, 1992a [1958], p. 35), escreveu Wittgenstein em 1931. Mas as disformidades do pensamento de Wittgenstein são as disformidades do pensamento de seu leitor? ${ }^{6}$

\section{Uma interpretação superficial das formas de nossa linguagem corrente}

Além de ter estendido às demais pessoas seus mal-entendidos que concerniam ao uso das palavras, Wittgenstein atribuiu uma má interpretação da linguagem ao logicismo. Nas Observações sobre os fundamentos da matemática $(\mathrm{V}, \S 48)$, por exemplo, Wittgenstein afirma:

A 'lógica matemática' deformou totalmente o pensamento de matemáticos e filósofos, já que, como análise das estruturas dos atos, instaurou uma interpretação superficial das formas de nossa linguagem corrente. $O$ único que fez a este respeito, certamente, é ter continuado edificando sobre a lógica aristotélica. ${ }^{7}$

Mas a quem a lógica matemática poderia parecer ter instaurado uma interpretação superficial das formas de nossa linguagem corrente? Reveladoramente, Wittgenstein argumenta na Gramática filosófica (p. 207):

A real dificuldade encontra-se no conceito de " $(\exists n) "$ e, em geral, de " $(\exists x) "$.
A fonte original dessa notação é a expressão de nossa linguagem de
palavras: "Existe um... com tais e tais propriedades". E, no caso, o que
substitui os pontos é algo como "livro da minha biblioteca" ou "coisa
(corpo) nesta sala", "palavra nesta carta" etc. Pensamos em objetos pelos
quais podemos passar um após o outro. Como tantas vezes acontece, um
processo de sublimação transformou essa forma em "há um objeto tal
que..." e, aqui também, as pessoas imaginaram originalmente os objetos
do mundo como iguais a "objetos" na sala (mesas, cadeiras, livros etc.),

\footnotetext{
${ }^{6}$ Em se tratando de pensamento, é curioso que a filosofia da mente de Wittgenstein se baseie na ideia de que não pensamos com as nossas cabeças ou nelas (e.g. WITTGENSTEIN, 1992b [1967], § 605, § 608, § 609; 2003 [1969], p. 78). Para uma investigação desse aspecto da filosofia wittgensteiniana a que seus comentadores nunca deram a devida atenção, ver Silva (2018b).

7 Para uma discussão sobre como Wittgenstein "deformou totalmente" a lógica aristotélica, sem sequer ter lido Aristóteles (DRURY, 1984b, p. 158), ver Silva (2016 e 2017, cap. 1).
}

SILVA, Gustavo Augusto Fonseca. A filosofia de Ludwig Wittgenstein à luz do diagnóstico de autismo. Griot : Revista de Filosofia, Amargosa - BA, v.19, n.1, p.226-253, fevereiro, 2019. 
embora esteja claro que, em muitos casos, a gramática dessa " $\exists x)$ etc." não seja a mesma que a gramática do caso primitivo que serve como paradigma. A discrepância entre a imagem original e aquela à qual a notação agora é aplicada torna-se particularmente palpável quando uma proposição como "há dois círculos neste quadrado" é traduzida como "não há nenhum objeto que tenha a propriedade de ser um círculo neste quadrado". A proposição "há apenas duas coisas que são círculos neste quadrado" (interpretada sobre o modelo da proposição "há apenas dois homens que escalaram esta montanha") parece louca, com boa razão. Isto é, não se ganha nada ao forçar a proposição "há dois círculos neste quadrado" nessa forma; só ajuda a ocultar que não esclarecemos a gramática da proposição. Mas, ao mesmo tempo, a notação russelliana, no caso, nos dá uma aparência de exatidão que faz as pessoas acreditarem que os problemas são resolvidos colocando a proposição em uma forma russelliana. [...]

"Uma das quatro pernas desta mesa não se segura", "Há ingleses com cabelos negros", "Há uma mancha nesta parede", "Os dois vasos têm o mesmo peso", "Há o mesmo número de palavras em cada uma das duas páginas". Em todos esses casos, na notação russelliana, o " $\exists$...)..." é usado e, cada vez, com uma gramática diferente. O que quero dizer é que se ganha pouca coisa traduzindo tal sentença da linguagem das palavras para a notação russelliana.

E o que quero dizer é que se ganha pouca coisa com essas considerações gramaticais de Wittgenstein. Quero dizer ainda que o filósofo G. F. Warnock - um dos "adeptos de WII", como Russell (1960 [1959], p. 194) denominou os discípulos do segundo Wittgenstein - fez críticas semelhantes à notação russelliana antes da publicação da Gramática filosófica, as quais foram devidamente refutadas por Russell (ibid., p. 206-213) com o auxílio de uma fábula sobre os "isidianos". Segundo Russell, os isidianos eram um povo cuja linguagem continha as palavras "barrigudinho", "truta", "perca" e "lúcio", mas não a palavra "peixe". Certo dia, um grupo de isidianos pescou o que chamamos de salmão. Sem terem um nome próprio para aquele animal, eles discutiram furiosamente sobre como deveriam chamá-lo. Um desconhecido que os viu naquela situação disse-lhes que sua tribo tinha uma palavra que se aplicava igualmente a barrigudinhos, trutas, percas, lúcios e àquele animal que eles tinham pescado: "peixe". Os isidianos, no entanto, consideraram essa palavra como um pedantismo inútil. "Diz Mr. Warnock que o numeral existencial confunde coisas que a linguagem comum distingue", observa Russell ao fim da fábula. "Isso é exatamente como se os isidianos tivessem se queixado de que um homem que usa a palavra "peixe" confunde barrigudinhos com lúcios" (ibid., p. 208).

Por acreditar que a notação russelliana confunde coisas que a linguagem comum distingue, Wittgenstein apresentou algumas considerações gramaticais semelhantes às da Gramática filosófica em uma aula de filosofia da matemática de 1939 e por fim concluiu:

Essas discussões tiveram um ponto: mostrar a diferença essencial entre os usos de proposições matemáticas e os usos de proposições não matemáticas que parecem ser exatamente análogas com elas.

Proposições matemáticas são em primeiro lugar sentenças inglesas; não apenas sentenças inglesas, mas cada proposição matemática tem uma

SILVA, Gustavo Augusto Fonseca. A filosofia de Ludwig Wittgenstein à luz do diagnóstico de autismo. Griot : Revista de Filosofia, Amargosa - BA, v.19, n.1, p.226-253, fevereiro, 2019. 
semelhança com algumas proposições não matemáticas. - Matemáticos, quando começam a filosofar, sempre cometem o erro de ignorar a diferença de função entre proposições matemáticas e proposições não matemáticas (WITTGENSTEIN, 1989, p. 111).

Mas quais matemáticos, quando começam a filosofar, sempre cometem o erro de ignorar a diferença de função entre proposições matemáticas e proposições não matemáticas? Além disso, a quem as proposições matemáticas poderiam parecer exatamente análogas às proposições não matemáticas? A quem poderia parecer relevante esclarecer que "os enunciados de número em matemática (por exemplo, “A equação $\mathrm{x}^{2}=1$ tem 2 raízes') são [...] um tipo de coisa bem diferente dos enunciados de número fora da matemática ('Há 2 maçãs na mesa')" (WITTGENSTEIN, 2003 [1969], p. 275)? E quem poderia acreditar que os problemas da filosofia da matemática nascem quando a linguagem entra em férias?

Todos os erros que foram cometidos neste capítulo da filosofia da matemática baseiam-se na confusão entre propriedades internas de uma forma (uma regra como uma entre uma lista de regras) e o que chamo de 'propriedades' na vida cotidiana (o vermelho como uma propriedade deste livro). Também poderíamos dizer: as contradições e obscuridades são ocasionadas por pessoas usando uma única palavra, por exemplo, 'número', para designar em uma ocasião um conjunto definido de regras e, em outro, um conjunto variável, como designar como 'xadrez' em uma ocasião o jogo definido que jogamos hoje e, em outra, o substrato de um desenvolvimento histórico particular (ibid., p. 382).

Por motivos que agora compreendemos, todos os erros que foram cometidos por Wittgenstein neste capítulo da filosofia da matemática baseiam-se na sua confusão entre propriedades internas de uma forma e o que ele chamou de "propriedades" na vida cotidiana. Também poderíamos dizer: suas contradições e obscuridades eram ocasionadas por pessoas usando uma única palavra em diferentes domínios da nossa linguagem. Erros, contradições e obscuridades que Wittgenstein estendeu aos matemáticos e aos demais filósofos. ${ }^{8}$

\section{Uma expressão de mal-estar mental}

No mesmo período em que escreveu a Gramática filosófica, Wittgenstein disse a seus alunos em uma aula: "O uso de uma palavra é o que é definido pelas regras, assim como o uso do rei no xadrez é definido pelas regras" (WITTGENSTEIN, 2001, p. 48). Mas ponderou:

Devemos comparar o uso da linguagem a jogar um jogo de acordo com regras exatas porque todos os problemas filosóficos surgem de estabelecerse um sistema tão simples de regras. Os filósofos tentam tabular as regras,

\footnotetext{
${ }^{8}$ Para uma análise de outros aspectos do pensamento matemático wittgensteiniano que justificam o fato de que "a maioria da filosofia analítica dominante ainda parece muito escandalizada pela filosofia da matemática de Wittgenstein para considerá-la muito seriamente" (KUUSELA; MCGINN, 2014a, p. 7, n. 6), ver Silva (2018a e 2018c).
}

SILVA, Gustavo Augusto Fonseca. A filosofia de Ludwig Wittgenstein à luz do diagnóstico de autismo. Griot : Revista de Filosofia, Amargosa - BA, v.19, n.1, p.226-253, fevereiro, 2019. 
e porque há tantas coisas a extraviá-los, por exemplo, analogias, eles estabelecem errado as regras (ibid.).

Mas todos os problemas filosóficos de fato surgem de estabelecer-se uma linguagem com regras exatas? Além do mais, quais filósofos foram extraviados pelas analogias que Wittgenstein investigou por tantos anos, como a analogia entre o tempo e um rio? "Nós falamos do fluir do tempo e consideramos sensato falar de seu fluxo, dada a analogia com os rios" (ibid., p. 13), alertou Wittgenstein em outra aula do início dos anos 1930. Mas a quem poderia parecer insensato falar do fluxo do tempo, dada a velha analogia com os rios? Sintomaticamente, Wittgenstein propôs aos alunos imaginar um rio no qual toras numeradas estivessem fluindo, de tal modo que seria possível descrever eventos na terra com referência a elas: "Quando a $105^{\text {a }}$ tora passou, eu jantei", exemplificou (ibid.). Com base nessa imagem das toras numeradas fluindo num rio, Wittgenstein argumentou mais adiante:

Suponha que as toras que passam pareçam estar à mesma distância. Nós temos uma experiência do que pode ser chamado a velocidade delas (mas não o que é medido por um relógio). Digamos que o rio move-se uniformemente nesse sentido. Mas, se nós dissermos que o tempo passou mais rapidamente entre as toras 1 e 100 do que entre as toras 100 e 200, esta é só uma analogia; na verdade nada passou mais rapidamente. Dizer que o tempo passou mais rapidamente, ou que o tempo flui, é imaginar alguma coisa fluindo. Nós então estendemos o símile e falamos sobre a direção do tempo. Quando as pessoas falam da direção do tempo, exatamente a analogia com o rio está diante delas. É claro que o rio pode mudar o fluxo de sua direção, mas tem-se a sensação de vertigem quando se fala de o tempo ser revertido. A razão é que a noção de fluir, de alguma coisa, e da direção do fluxo está incorporada em nossa linguagem (ibid., p. 14).

Mas, quando as pessoas falam da direção do tempo, a analogia com o rio está necessariamente diante delas? Ora, é claro que não. Além disso, é verdade que o rio pode mudar o fluxo de sua direção, diferentemente do tempo, que não pode ser revertido. Mas quem poderia ter a sensação de vertigem quando se fala de o tempo ser revertido? A quem a noção de fluir, de alguma coisa, e da direção do fluxo poderia causar a sensação de vertigem por estar incorporada em nossa linguagem? E quem poderia acreditar que os problemas filosóficos relativos ao tempo nascem quando a linguagem entra em férias?

Pode o tempo seguir separado dos eventos? Qual é o critério para o tempo envolvido em "Eventos começaram 100 anos atrás e o tempo começou 200 anos atrás"? O tempo foi criado ou o mundo foi criado no tempo? Estas questões são feitas dada a analogia com "Esta cadeira foi criada?" e são como perguntar que ordem foi criada (uma "antes" e "depois"). "Tempo" é um substantivo terrivelmente enganador. Nós tivemos que criar as regras do jogo antes de jogá-lo. Discutir o "fluxo do tempo" mostra como os problemas filosóficos surgem. Problemas filosóficos são causados por não se usar a linguagem praticamente, mas por estender-se em sua observação. Nós formamos sentenças e depois nos perguntamos o que elas podem significar. Uma vez conscientes de "tempo" como um substantivo, nós perguntamos então sobre a criação do tempo (ibid., p. 14-15).

SILVA, Gustavo Augusto Fonseca. A filosofia de Ludwig Wittgenstein à luz do diagnóstico de autismo. Griot : Revista de Filosofia, Amargosa - BA, v.19, n.1, p.226-253, fevereiro, 2019. 
E, uma vez conscientes da consideração gramatical de Wittgenstein sobre o substantivo "tempo", algum mal-entendido, algum engano nosso é afastado? Afinal, a quem o substantivo "tempo" poderia ser terrivelmente enganador? A quem o "fluxo do tempo" poderia ser tão problemático? E a quem poderia ser tão confuso o fato de que "a maior parte de nosso entendimento do tempo é uma versão metafórica de nosso entendimento do movimento no espaço" (LAKOFF: JOHNSON, 1999, p. 139)? ${ }^{9}$

Ainda às voltas com questões relativas ao tempo, sobre o qual advertiu que "pode nos enganar, fazendo com que persigamos (aqui e ali) um fantasma" (WITTGENSTEIN, 2010a [1997], p. 112), Wittgenstein sugeriu na Gramática filosófica (p. 145):

Consideremos um problema filosófico particular, como "Como é possível medir um período de tempo, já que o passado e o futuro não estão presentes e o presente é apenas um ponto?". O traço característico disso é que uma confusão é expressa na forma de uma pergunta que não reconhece a confusão, e que o que libera o perguntador de seu problema é uma alteração particular de seu método de expressão.

No Livro azul (p. 58-59), Wittgenstein retoma a discussão sobre o tempo e sobre como é possível medi-lo atribuindo a Santo Agostinho uma confusão que ele jamais fez ${ }^{10}$ :

Considerem como um exemplo a questão "O que é o tempo?", tal como foi formulada por Santo Agostinho e outros. [...] é a gramática da palavra "tempo" que nos deixa perplexos. Nós apenas expressamos esta perplexidade ao formular uma questão um pouco enganadora, a questão: “O que é...?" Esta questão é uma expressão de falta de clareza, de malestar mental, e é comparável à questão "por quê?" que as crianças repetem tão frequentemente. [...] Ora a perplexidade sobre a gramática da palavra "tempo" provém do que se poderia chamar as contradições aparentes dessa gramática.

Foi uma dessas "contradições" que embaraçou Santo Agostinho quando argumentou: Como é possível a medição do tempo? O passado não pode ser medido, porque passou, e o futuro não pode ser medido porque ainda não existe. E o presente não pode ser medido porque não tem extensão.

A contradição que aqui parece notar-se poderia ser considerada um conflito entre dois usos diferentes de uma palavra, neste caso a palavra "medir". Poderíamos dizer que Santo Agostinho pensa no processo de medição de um comprimento: por exemplo, a distância entre duas marcas numa fita que se desenrola perante nós e da qual apenas podemos ver um minúsculo fragmento (o presente). A resolução deste enigma consistirá na comparação daquilo a que nos referimos por "medição" (a gramática da palavra "medição"), quando a aplicamos a uma distância numa fita, com a

\footnotetext{
${ }^{9}$ Para uma introdução às pesquisas na linguística cognitiva sobre como o tempo é estruturado metaforicamente em termos espaciais, ver Evans (2015).

10 Para um exame detalhado de como Wittgenstein também atribuiu injustamente a Santo Agostinho uma concepção da linguagem aos moldes da teoria pictórica do significado (Tractatus logico-philosophicus), deturpou o trabalho de lógicos como Frege e Russell e apresentou ideias linguísticas triviais nas Investigações filosóficas, ver Silva (2016 e 2017 , cap. 1).
}

SILVA, Gustavo Augusto Fonseca. A filosofia de Ludwig Wittgenstein à luz do diagnóstico de autismo. Griot : Revista de Filosofia, Amargosa - BA, v.19, n.1, p.226-253, fevereiro, 2019. 
gramática da palavra quando esta é aplicada ao tempo. O problema pode parecer simples, mas a sua extrema dificuldade deve-se ao fascínio que a analogia entre duas estruturas semelhantes na nossa linguagem pode exercer sobre nós.

Para Wittgenstein, portanto, a gramática da palavra "tempo" é que nos deixa perplexos e a extrema dificuldade do problema deve-se ao fascínio que a analogia entre duas estruturas semelhantes na nossa linguagem pode exercer sobre nós. Mas há de fato tal "fascínio" sobre nós? Sem fascínio algum, Santo Agostinho pergunta-se nas Confissões (XI, 21): "Que medimos, senão o tempo em um determinado espaço? Quando dizemos de um tempo que é simples, duplo, ou triplo, ou igual, ou quando formulamos qualquer outra relação dessa espécie, nada mais fazemos do que medir espaços de tempo". Também não há fascínio ou um conflito entre os usos da palavra "medir", quando aplicada ao tempo e ao espaço, nos outros poucos filósofos que Wittgenstein leu (MONK, 2005, p. 6-14). ${ }^{11}$ Nem em Aristóteles, que afirma nas Categorias (VI):

Também o tempo e o espaço são contínuos. O tempo é um todo e contínuo: o presente, o passado e o futuro estão vinculados. O espaço é também este tipo de quantidade, pois uma vez que as partes mesmas do sólido ocupam um certo espaço e estas partes possuem um limite em comum, conclui-se que também as partes do espaço, que aquelas próprias partes ocupam, possuem exatamente o mesmo limite ou termo comum das partes do sólido. Como o tempo, é o espaço, portanto, contínuo: suas partes se reúnem numa fronteira comum.

Dado que o tempo e o espaço são contínuos, aplicamos a ambos a palavra "medir", sem que haja um conflito entre seus dois usos diferentes. Além disso, a questão "O que é o tempo?", tal como foi formulada por Santo Agostinho e outros, não é uma questão um pouco enganadora, nem é uma expressão de falta de clareza, de mal-estar mental. O próprio Santo Agostinho questiona-se nas Confissões sobre o tempo por crer que "nos fez o que permanece eternamente" (IX, 10), com sua

${ }_{11}$ Há registros de que Wittgenstein demonstrava orgulho de não ter estudado outros filósofos (e.g. MONK, 1995 [1990], p. 438). É possível que se trate de um mecanismo de defesa, já que existem evidências e relatos do próprio Wittgenstein de que ele tinha dificuldades de leitura e de escrita. Em certa ocasião, por exemplo, Wittgenstein afirmou: "Minha má ortografia na juventude, até os dezoito ou dezenove anos, está ligada com todo o resto de minha pessoa (minha fraqueza nos estudos)" (MCGUINNESS, 2005 [1988], p. 52). Em dezembro de 1933, por sua vez, Wittgenstein pediu a W. H. Watson: "Por favor, não me envie seu manuscrito. Eu não poderei olhá-lo. Eu gostaria muito de ver você e discutir as coisas com você, mas eu não sou bom de leitura! Ler me desgasta enormemente e eu não chego a lugar algum" (MCGUINNESS, 2012 [1995], p. 216). Já em dezembro de 1947, Wittgenstein comentou em carta a Von Wright: "Eu dificilmente leio alguma coisa: algumas histórias de detetives e algumas outras coisas que eu já li muitas vezes. Leitura de verdade é sempre ruim para mim" (ibid., p. 420). Tendo certamente percebido as dificuldades de leitura de Wittgenstein, Piero Sraffa era didático ao escrever para ele, como exemplifica sua carta datada de pouco depois da anexação da Áustria pela Alemanha nazista (MONK, 1995 [1990], p. 351-352). É revelador que Sraffa inicie o texto dizendo que sua análise seria "provavelmente confusa" e ao fim desculpe-se pela "carta confusa" - "levando-nos", segundo Monk (ibid., p. 352), "a imaginar que níveis de clareza e precisão ele atingia no resto de sua correspondência". Ou melhor, à luz do diagnóstico póstumo de autismo: levando-nos a imaginar que níveis de clareza e precisão ele tinha de atingir para se fazer entender por Wittgenstein, que não apenas lia frequentemente com amigos como chegava a pedir que lessem para ele (e.g. DRURY, 1984b, p. 115; MALCOLM, 1990 [1958], p. 86; MONK, 1995 [1990], p. 282 e p. 503; SOMAVILLA, 2010, p. 202).

SILVA, Gustavo Augusto Fonseca. A filosofia de Ludwig Wittgenstein à luz do diagnóstico de autismo. Griot : Revista de Filosofia, Amargosa - BA, v.19, n.1, p.226-253, fevereiro, 2019. 
"verdade imutável" (XI, 8). Assim, a perplexidade de Santo Agostinho diante da pergunta sobre o que é o tempo não provém do que se poderia chamar as contradições aparentes da gramática dessa palavra, como afirmou Wittgenstein. Por isso, Agostinho não se liberaria da pergunta sobre o que é o tempo e sobre como é possível medi-lo se alterasse o seu método de expressão, porque definitivamente não se trata de uma confusão expressa na forma de uma pergunta que não reconhece a confusão.

\section{Considerações finais}

$O$ fato de Wittgenstein ter estendido às demais pessoas seus "constrangimentos mentais" - dos quais os exemplos aqui discutidos são evidentemente uma pequena amostra - de modo algum surpreende. Surpreende, no entanto, que toda uma escola não apenas tenha encontrado importante sabedoria em sua concepção filosófica como tenha dado continuidade às suas doutrinas negativas. Um dos mais importantes representantes dessa escola, Peter Strawson avalia em Análise e metafísica que a imagem do "filósofo analítico como uma espécie de terapeuta, que busca curar certos tipos de desarranjos mentais" (p. 15), pode parecer muito implausível e talvez chocante, sendo na verdade "exagerada e unilateral" ( $p$. 16). Não obstante isso, Strawson acredita que a concepção filosófica de Wittgenstein tem os seus méritos, já que instigou questões para as quais foram dadas respostas, entre as quais: Como é que esses desarranjos surgem? Que formas assumem? Como é que se curam ou se corrigem? Nas palavras de Strawson, foram estas as respostas oferecidas a tais perguntas:

\footnotetext{
Os desarranjos nunca acontecem quando os conceitos, as ideias, estão sendo efetivamente empregues por nós; só quando estão ociosos. Podemos ser vítimas de outros tipos de confusão, deparar com outros problemas quando usamos as palavras que expressam as ideias na atividade significativa que lhe é própria; mas nesse caso não se trata de confusões ou problemas filosóficos. Defrontamo-nos com esses problemas ou essas confusões filosóficas somente quando permitimos que os conceitos ou as palavras se desliguem do seu uso corrente, dos interesses práticos ou teóricos que constituem a sua significação; quando os conceitos se deslocam ociosos ou flutuam na mente. Quando isso acontece, todos os tipos de paralelismos gramaticais superficiais, figuras tradicionais de linguagem, metáforas, modelos ou imagens inapropriadas tomam conta do pensamento e arrastam-nos para o paradoxo, em direção ao absurdo, ao mito ou para a confusão sem remédio (ibid., p. 16-17).
}

Mas quem poderia ser arrastado para o paradoxo, em direção ao absurdo, ao mito ou para a confusão sem remédio quando todos os tipos de paralelismos gramaticais superficiais, figuras tradicionais de linguagem, metáforas, modelos ou imagens inapropriadas tomam conta do pensamento? E quem poderia precisar das curas a esses "desarranjos mentais" oferecidas primeiramente por Wittgenstein e depois por seus adeptos? Eis a pergunta que cada leitor de Wittgenstein e de seus discípulos deve se fazer e responder apenas por si mesmo.

SILVA, Gustavo Augusto Fonseca. A filosofia de Ludwig Wittgenstein à luz do diagnóstico de autismo. Griot : Revista de Filosofia, Amargosa - BA, v.19, n.1, p.226-253, fevereiro, 2019. 


\section{Referências}

ARISTÓTELES. Órganon: Categorias, Da interpretação, Analíticos anteriores, Analíticos posteriores, Tópicos, Refutações sofísticas. 2. ed. Tradução de Edson Bini. São Paulo: Edipro, 2010.

AYER, A. J. Ludwig Wittgenstein. Londres: Penguin Books, 1985.

BOUWSMA, O. K. Conversas com Wittgenstein. Tradução de Miguel S. Pereira. Lisboa: Relógio D’Água Editores, 2005.

BUCHHOLZ, Kai. Compreender Wittgenstein. 2. ed. Tradução de Vilmar Schneider Petrópolis: Editora Vozes, 2009. (Série Compreender).

DABROWSKA, E.; DIV JAK, D. (Eds.). Handbook of Cognitive Linguistics. Berlim; Boston: De Gruyter Mouton, 2015.

DILMAN, I. Wittgenstein's Copernican Revolution: The Question of Linguistic Idealism. Basingstoke: Palgrave Macmillan, 2002.

DRURY, M. O'C. Some notes on conversations with Wittgenstein. In RHEES, Rush (Ed.). Recollections of Wittgenstein: Hermine Wittgenstein; Fania Pascal; F. R. Leavis; John King; M. O'c. Drury. Oxford: Oxford University Press, 1984a, p. 76-96. DRURY, M. O'C. Conversations with Wittgenstein. In: RHEES, Rush (Ed.). Recollections of Wittgenstein: Hermine Wittgenstein; Fania Pascal; F. R. Leavis; John King; M. O'c. Drury. Oxford: Oxford University Press, 1984b, p. 97-171.

EDMONDS, David; EIDINOW, John. O atiçador de Wittgenstein: a história de uma discussão de dez minutos entre dois grandes filósofos. Tradução de Pedro Jorgensen Júnior. Rio de Janeiro: Difel, 2003.

EVANS, V. Time. In: DABROWSKA, E.; DIVJAK, D. (Eds.). Handbook of Cognitive Linguistics. Berlim; Boston: De Gruyter Mouton, 2015, p. 509-526.

FITZGERALD, Michael. Did Ludwig Wittgenstein have Asperger's syndrome? European Child \& Adolescent Psychiatry, março de 2000, v. 9, p. 61-65, 2000.

FOGELIN, Robert J. Wittgenstein. 2. ed. Londres; Nova York: Routledge, 1995.

FREGE, Gottlob. Os fundamentos da aritmética. In: FREGE, Gottlob; PEIRCE, Charles Sanders. Escritos coligidos; Sobre a justificação científica de uma conceitografia; Os fundamentos da aritmética. São Paulo: Editora Abril, 1974, p. 203-282.

FREGE, Gottlob; PEIRCE, Charles Sanders. Escritos coligidos; Sobre a justificação científica de uma conceitografia; Os fundamentos da aritmética. São Paulo: Editora Abril, 1974.

GILLBERG, Christopher. A guide to Asperger Syndrome. Cambridge: Cambridge University Press, 2002.

GLOCK, Hans-Johann. Dicionário Wittgenstein. Tradução de Helena Martins. Revisão técnica de Luiz Carlos Pereira. Rio de Janeiro: Jorge Zahar, 1998.

GOLDSTEIN, Rebecca. Incompletude: a prova e o paradoxo de Kurt Gödel. Tradução de Ivo Korytowski. São Paulo: Companhia das Letras, 2008.

HSIANG, Wu Yi. A concise introduction to calculus. Cingapura, Nova Jersey, Londres, Hong Kong: World Scientific, 1995.

ISHISAKA, Yoshiki. Wittgenstein and Asperger Syndrome: I. Did Wittgenstein Have This Syndrome? Japanese Journal of Child and Adolescent Psychiatry, vol. 44, n. 3, p. 231-251, 2003a.

SILVA, Gustavo Augusto Fonseca. A filosofia de Ludwig Wittgenstein à luz do diagnóstico de autismo. Griot : Revista de Filosofia, Amargosa - BA, v.19, n.1, p.226-253, fevereiro, 2019. 
ISHISAKA, Yoshiki. Wittgenstein and Asperger Syndrome: II. Wittgenstein's Cognitive Styles. Japanese Journal of Child and Adolescent Psychiatry, vol. 44, n. 3, p. 252-275, 2003b.

JANIK, Allan; TOULMIN, Stephen. A Viena de Wittgenstein. Tradução de Álvaro Cabral. Rio de Janeiro: Editora Campus, 1991.

KUUSELA, Oskari; MCGINN, Marie. Editors'introduction. In: KUUSELA, Oskari; MCGINN, Marie (Eds.). The Oxford Handbook of Wittgenstein. Oxford: Oxford University Press, 2014a, p. 3-12.

KUUSELA, Oskari; MCGINN, Marie (Eds.). The Oxford Handbook of Wittgenstein. Oxford: Oxford University Press, 2014b.

LAKOFF, George; JOHNSON, Mark. Philosophy in the flesh: the embodied mind and its challenge to western thought. Nova York: Basic Books, 1999.

MALCOLM, Norman. Ludwig Wittgenstein: esbozo biografico de G. H. von Wright. Tradução espanhola de Mario Garcia Aldonate. Madri: Biblioteca Mondadori, 1990.

MCGUINNESS, Brian. Approaches to Wittgenstein: collected papers. Londres; Nova York: Routledge, 2002.

MCGUINNESS, Brian. Young Ludwig: Wittgenstein's life, 1889-1921. Oxford: Clarendon Press, 2005.

MCGUINNESS, Brian. Wittgenstein in Cambridge: letters and documents, 19111951. Oxford: Blackwell, 1995. 4. ed. Oxford: Wiley-Blackwell, 2012.

MCGUINNESS, Brian; VON WRIGHT, G. H. (Eds.). Ludwig Wittgenstein: Cambridge Letters - Correspondence with Russell, Keynes, Moore, Ramsey and Sraffa. Oxford e Malden: Blackwell Publishers, 1997.

MONK, Ray. How to read Wittgenstein. Nova York: Norton, 2005.

MONK, Ray. Wittgenstein: o dever do gênio. Tradução de Carlos Afonso Malferrari. São Paulo: Companhia das Letras, 1995.

PASCAL, Fania. Wittgenstein: a personal memoir. In: RHEES, Rush (Ed.). Recollections of Wittgenstein: Hermine Wittgenstein; Fania Pascal; F. R. Leavis; John King; M. O'c. Drury. Oxford: Oxford University Press, 1984, p. 12-49.

RHEES, Rush (Ed.). Recollections of Wittgenstein: Hermine Wittgenstein; Fania Pascal; F. R. Leavis; John King; M. O'c. Drury. Oxford: Oxford University Press, 1984.

RUSSELL, Bertrand. Autobiografia de Bertrand Russell. Tradução de Brenno Silveira. Rio de Janeiro: Civilização Brasileira, 1967. 3v.

RUSSELL, Bertrand. Meu pensamento filosófico. Tradução de Brenno Silveira. São Paulo: Companhia Editora Nacional, 1960.

RUSSELL, Bertrand. The principles of mathematics. Cambridge: Cambridge University Press, 1903. 2. ed. Londres: George Allen and Unwin, 1937.

SANTO AgOSTINHO. A doutrina cristã. 3. ed. Tradução do original latino, cotejada com versões em francês e espanhol e introdução de Ir. Nair Assis Oliveira. São Paulo: Paulus, 2011. (Coleção Patrística).

SANTO AgOSTINHO. Confissões. Tradução de Frederico Ozanam Pessoa de Barros. Introdução de Pe. Riolando Azzi. Rio de Janeiro: Saraiva de Bolso, 2012.

SILVA, Gustavo A. F. Jogos de signos, jogos de linguagem: um estudo comparativo entre a linguística de Ferdinand de Saussure e a filosofia de Ludwig Wittgenstein.

SILVA, Gustavo Augusto Fonseca. A filosofia de Ludwig Wittgenstein à luz do diagnóstico de autismo. Griot : Revista de Filosofia, Amargosa - BA, v.19, n.1, p.226-253, fevereiro, 2019. 
Dissertação (Mestrado em Estudos Linguísticos) - Faculdade de Letras, Universidade Federal de Minas Gerais, 2017.

SILVA, Gustavo A. F. Observações sobre a filosofia da matemática de Ludwig Wittgenstein. Griot: Revista de Filosofia, n. 17, v. 1, p. 97-113, 2018a.

SILVA, Gustavo A. F. Observações sobre a filosofia da mente de Ludwig Wittgenstein. Problemata, v. 9, n. 4, p. 218-233, 2018b.

SILVA, Gustavo A. F. Observações sobre a meta final do modo de fazer filosofia de Ludwig Wittgenstein. Principia: An International Journal of Epistemology, v. 22, n. 3 , p. 411-438, 2018c.

SILVA, Gustavo A. F. Sobre a obviedade das 'ideias mais fecundas' das Investigações filosóficas. IF-SOPHIA, v. II, p. 203-221, 2016.

SNOWDON, Paul. Private experience and sense data. In: KUUSELA, Oskari; MCGINN, Marie (Eds.). The Oxford Handbook of Wittgenstein. Oxford: Oxford University Press, 2014b, p. 402-428.

SOMAVILLA, Ilse. Notas e comentários. In: WITTGENSTEIN, Ludwig. Movimentos de pensamento: diários de 1930-32/1936-37. Tradução de Edgar da Rocha Marques. São Paulo: Martins Fontes, 2010a, p. 165-252.

STRAWSON, Peter F. Análise e metafísica: uma introdução à filosofia. Tradução de Armando Mora de Oliveira. São Paulo: Discurso Editorial, 2002.

VON WRIGHT, G. H. Esbozo biográfico. In: MALCOLM, Norman. Ludwig Wittgenstein: esbozo biografico de G. H. von Wright. Tradução espanhola de Mario Garcia Aldonate. Madri: Biblioteca Mondadori, 1990, p. 11-31.

WILLIAMS, Chris; WRIGHT, Barry. Convivendo com autismo e síndrome de Asperger: estratégias para pais e profissionais. Tradução de Cássia Maria Nasser. São Paulo: M. Books, 2008.

WITTGENSTEIN, Ludwig. Cultura e valor. Tradução de Jorge Mendes. Lisboa: Edições 70, 1992a.

WITTGENSTEIN, Ludwig. Fichas (Zettel). Tradução de Ana Berhan da Costa. Lisboa: Edições 70, 1992b.

WITTGEnSteIN, Ludwig. Gramática filosófica. Tradução de Luís Carlos Borges. São Paulo: Loyola, 2003.

WITTGENSTEIN, Ludwig. Investigações filosóficas. Tradução de José Carlos Bruni. São Paulo: Abril Cultural, 1999. (Coleção: Os pensadores).

WITTGENSTEIN, Ludwig. Movimentos de pensamento: diários de 1930-32/1936-37. Tradução de Edgar da Rocha Marques. São Paulo: Martins Fontes, 2010a.

WITTGENSTEIN, Ludwig. Observaciones sobre los fundamentos de la matemática. Tradução espanhola de Isidoro Reguera. Madri: Alianza Editorial, 1987.

WITTGENSTEIN, Ludwig. Observações filosóficas. Tradução de Adail Sobral e Maria Stela Gonçalves. São Paulo: Loyola, 2005a.

WITTGENSTEIN, Ludwig. Observações sobre a filosofia da psicologia. Tradução de Ricardo Hermann Ploch Machado. Aparecida: Idéias \& Letras, 2008a.

WITTGEnSTEIN, Ludwig. O livro azul. Tradução de Jorge Mendes. Lisboa: Edições 70, 2008b.

WITTGENSTEIN, Ludwig. O livro castanho. Tradução de Jorge Marques. Lisboa: Edições 70, 1992c.

SILVA, Gustavo Augusto Fonseca. A filosofia de Ludwig Wittgenstein à luz do diagnóstico de autismo. Griot : Revista de Filosofia, Amargosa - BA, v.19, n.1, p.226-253, fevereiro, 2019. 
WITTGENSTEIN, Ludwig. The Big Typescript: TS 213. Oxford: Blackwell Publishing, 2005b.

WITTGENSTEIN, Ludwig. Tractatus logico-philosophicus. Tradução e ensaio introdutório de Luiz Henrique Lopes dos Santos. São Paulo: Edusp, 2010 b.

WITTGENSTEIN, Ludwig. Wittgenstein's lectures: Cambridge, 1932-1935. Ambrose, Alice; Macdonald, Margaret (Eds.). Amherst, N.Y.: Prometheus Books, 2001.

WITTGENSTEIN, Ludwig. Wittgenstein's lectures on the foundations of mathematics. Cambridge, 1939: from the notes of R. G. Bosanquet, Norman Malcolm, Rush Rhees, and Yorick Smythies. Diamond, Cora (Ed.). Chicago e Londres: The University of Chicago Press, 1989.

WITTGENSTEIN, Ludwig; WAISMANN, Friedrich. The voices of Wittgenstein: The Vienna Circle - Ludwig Wittgenstein and Friedrich Waismann. Baker, Gordon (Ed.). Londres: Routledge, 2003.

Autor(a) para correspondência: Gustavo Augusto Fonseca Silva, Universidade Federal de Minas Gerais, Faculdade de Letras, Av. Pres. Antônio Carlos, 6627 - Pampulha, 31270-901, Belo Horizonte MG, Brasil.fonsecaugusto@hotmail.com 